\title{
Synthetic Food Coloring as an Alternative to Worm Egg Staining Ascaris lumbricoides
}

\author{
Steven Soenjono ${ }^{1 *}(\mathbb{D})$ Budi Setiawan ${ }^{2,3}$ (D), Rahmah Siti Wulandari ${ }^{2}$, Suyana Suyana ${ }^{2}$, Marta Atik Martiningsih ${ }^{2}$ \\ ${ }^{1}$ Department of Environmental Health, Politeknik Kesehatan Kementerian Kesehatan Manado, Manado, Indonesia; ${ }^{2}$ Department of \\ Medical Laboratory Technology, Politeknik Kesehatan Kementerian Kesehatan Yogyakarta, Yogyakarta, Indonesia; ${ }^{3}$ Pusat Unggulan \\ IPTEKS Inovavsi Teknologi Kesehatan Masyarakat (PUINOVAKESMAS), Poltekkes Kemenkes Yogyakarta, Yogyakarta, Indonesia
}

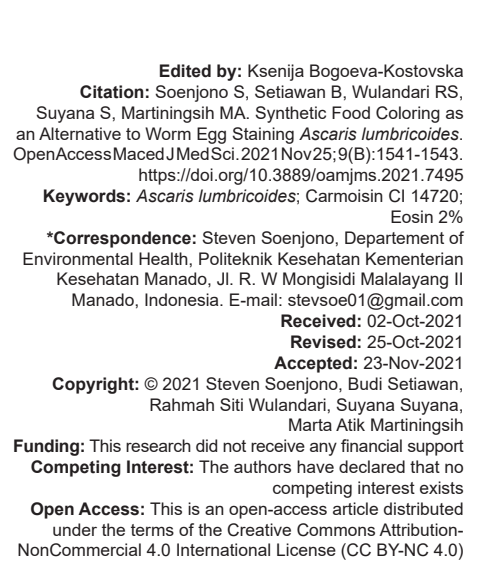

Abstract

BACKGROUND: Examination of worm eggs is a way of diagnosing helminthiasis by giving $2 \%$ eosin as a dye, but this reagent is carcinogenic so an alternative is needed to replace it. Synthetic food coloring (carmoisin $\mathrm{Cl}$ 14720) can staining worm eggs against a more contrasting background than eosin

AIM: The purpose of this study was to determine the synthetic food coloring with a concentration of $1 \%, 2 \%, 3 \%, 4 \%$, and $5 \%$ which can be used as an alternative to $2 \%$ eosin in the examination of Ascaris lumbricoides eggs.

METHODS: This type of research is observational with a cross-sectional research design. Positive stool samples for A. lumbricoides eggs were obtained from the Parasitology Laboratory of the University of Indonesia. Data were analyzed by ANOVA and interclass correlation coefficient (ICC) tests

RESULTS: The results of the ANOVA test showed that there was no difference between $2 \%$ eosin and food coloring. CONCLUSION: The results of the ICC test obtained a value of 0.845 , so the dye can be used as an alternative to $2 \%$ eosin in the examination of $A$. lumbricoides eggs.

\section{Introduction}

One-third of the world's population is infected with at least one species of soil-transmitted helminths (STHs) with Ascaris lumbricoides infecting 800 million people, Trichuris trichiura 600 million, and hookworm 600 million and causing up to 135,000 deaths annually [1]. STHs have also been classified among the most common neglected tropical diseases because they persist exclusively in the poorest populations (i.e., US\$1.25/day) and are thus often overlooked [2]. Individuals infected with STH may suffer from anemia, stunted growth, reduced physical fitness, and impaired cognitive development [3] which show a continued decline in socioeconomic development in low-income countries [4], [5].

At present, the identification of parasitic worms is more focused on examining eggs as the basis for determining the genus of worms, although it is generally known that many parasitic eggs are relatively the same [6]. Identification can be done in several ways, one of which is by direct (native) examination of the preparation. The dye reagent used in this examination is $2 \%$ eosin which is acidic, which can provide a red background and produce a red morula color and dark red wall color in worm eggs [7]. However, it is suspected that eosin can be a carcinogen in living things [8], therefore, alternative materials are needed to replace them.

One of the dyes that are easily available is synthetic dyes for food. The dye contains carmoisin dye with $\mathrm{Cl}$ code 144,720 which produces a dark red color. Carmoisin is a synthetic dye (water soluble) containing an azo structure and an aromatic ring [9] and not carcinogenic [10]. Many researches related to alternative materials to replace eosin have been carried out, but there has been no research using carmoisin to color A. lumbricoides eggs. In this study, we evaluated the quality of carmoisin as a potential alternative for staining $A$. lumbricoides compared to $2 \%$ eosin.

\section{Methods}

This research is observational analytic with cross-sectional study, feces examined with direct method. Samples of $A$. lumbricoides eggs were obtained from the Parasitology Laboratory of 
the University of Indonesia. The fecal sample was examined by 10 examiner to give a score with the criteria of a score of 1 , the preparation had a noncontrast field of view, the worm eggs did not absorb color and the egg part was not clear, the score was 2 , if the preparation had a less contrasting field of view, the worm eggs did not absorb color, and the eggs are not clearly visible, the score is 3 when the visual field is contrasting, the worm eggs absorb the color and the egg parts are clearly visible.

The data are presented in a table of each concentration then ANOVA analysis is carried out then followed by interclass correlation coefficient (ICC) analysis to determine the ICC value at each concentration to determine the reliability of the examination results.

\section{Results and Discussion}

Based on the research results shown in Figure 1 and Table 1, the food coloring used can color all parts of the egg, but the best concentration is at $2 \%$. Research conducted by Nurmufidah (2020), in the description of the variation in the concentration of Giemsa solution on the quality of STH worm egg preparations, it was found that the quality of preparations with the best quality at a concentration of $3 \%$ with a constant white background, easier, and more comfortable to distinguish with worm eggs, the embryo is purplish with a purplish-blue color on the egg wall of the Necator americanus/Ancylostoma duodenale with $150 \%$ effectiveness so that it can be used as a substitute for $2 \%$ eosin in the manufacture of worm egg preparations by the direct method. While this study used a synthetic food coloring carmoisin $\mathrm{Cl}$ 14720 with the results of the preparation that is a white background with pink eggs, morula can be seen clearly.

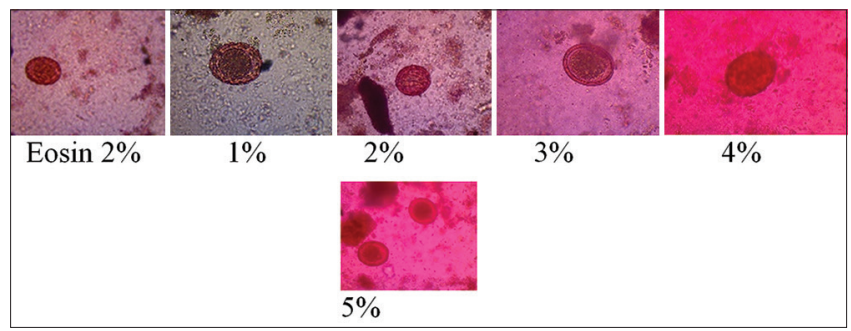

Figure 1: Microscopic view of staining worm eggs

The principle of staining on worm eggs is the affinity (formation of chemical bonds) between the tissue and the dye, either directly or indirectly [11]. Carmoisin Cl 14720 dye tends to be slightly alkaline [12]. This is evidenced by the examination of the $\mathrm{pH}$ of carmoisin $\mathrm{Cl} 44720$ at each concentration having the same $\mathrm{pH}$ of 7.5. Carmoisin $\mathrm{Cl} 14720$ contains an azo structure and an aromatic ring [13] Carmoisin uses propylene glycol as a solvent. Propylene glycol functions as a humectant that will maintain the stability of the preparation by
Table 1: Carmoisin staining analysis

\begin{tabular}{|c|c|c|c|c|c|c|c|}
\hline \multirow[t]{2}{*}{ Examiner } & \multicolumn{5}{|c|}{ Carmoisin dye concentration } & \multirow{2}{*}{$\begin{array}{l}\text { Eosin } \\
2 \%\end{array}$} & \multirow[t]{2}{*}{ ICC } \\
\hline & $1 \%$ & $2 \%$ & $3 \%$ & $4 \%$ & $5 \%$ & & \\
\hline 1 & 1 & 3 & 3 & 2 & 3 & 2 & 0.845 \\
\hline 2 & 2 & 3 & 3 & 1 & 2 & 3 & \\
\hline 3 & 3 & 3 & 3 & 2 & 2 & 3 & \\
\hline 4 & 3 & 2 & 3 & 2 & 2 & 3 & \\
\hline 5 & 3 & 3 & 3 & 2 & 2 & 3 & \\
\hline 6 & 3 & 3 & 2 & 2 & 2 & 2 & \\
\hline 7 & 3 & 3 & 3 & 3 & 3 & 3 & \\
\hline 8 & 3 & 3 & 3 & 3 & 3 & 3 & \\
\hline 9 & 3 & 3 & 2 & 1 & 2 & 3 & \\
\hline 10 & 3 & 3 & 3 & 2 & 2 & 3 & \\
\hline ANOVA test & 0.102 & 0.645 & 0.286 & 0.242 & 0.486 & & \\
\hline
\end{tabular}

reducing evaporation of water from the preparation and absorbing moisture from the environment [14].

Worm eggs contain albuminoid which is a type of protein [15]. Protein molecules have an amino group $(-\mathrm{NH} 2)$ and a carboxylic group $(-\mathrm{COOH})$ at the ends of the chain [16]. This causes the protein to have a lot of charge (polyelectrolyte) and is amphoteric, that is, it can react with acids and bases [17] then the chemical bond formed between carmoisin and protein is a carboxylic group reacting with $\mathrm{OH}$ - ions, the presence of a charge on the protein molecule causes the protein to move under the influence of an electric field [18] so that the negatively charged protein that causes $A$. lumbricoides worm eggs can be stained by positively charged carmoisin $\mathrm{Cl} 14720$.

\section{Conclusion}

Carmoisin Cl 14720 synthetic food coloring can be used as an alternative dye for $A$. lumbricoides worm eggs with an ICC value of 0.845 . Further research can examine the effect of the synthetic food coloring carmoisin $\mathrm{Cl} 14720$ on the examination of worm eggs with different worm eggs.

\section{References}

1. Hotez PJ. One world health: Neglected tropical diseases in a flat world. PLoS Negl Trop Dis. 2009;3(4):e405. http: doi. org/10.1371/journal.pntd.0000405 PMid:19399165

2. Liese B, Rosenberg M, Schratz A. Programmes, partnerships, and governance for elimination and control of neglected tropical diseases. Lancet. 2010;375(9708):67-76. http: doi.org/10.1016/ S0140-6736(09)61749-9

PMid:20109865

3. Bethony J, Brooker S, Albonico M, Geiger SM, Loukas A Diemert $\mathrm{D}$, et al. Soil-transmitted helminth infections: Ascariasis, trichuriasis, and hookworm. Lancet. 2006;367(9521):1521-32. http: doi.org/10.1016/S0140-6736(06)68653-4

PMid:16679166

4. King $\mathrm{CH}$. Parasites and poverty: The case of schistosomiasis. 
Acta Trop. 2010;113(2):95-104. http://doi.org/10.1016/j. actatropica.2009.11.012

PMid:19962954

5. World Health Organization. Deworming for Health and Development: Report of the $3^{\text {rd }}$ Global Meeting of the Partners for Parasite Control. Geneva: World Health Organization; 2005.

6. Hanafiah M, Dwinna A, Mahdi A, Karmil F, Rachmady D. Detection of parasitic helminths in cattle from Banda Aceh, Indonesia. Vet World. 2019;12(8):1175. http://doi.org/10.14202/ vetworld.2019.1175-1179

PMid:31641294

7. Oktari A, Mu'tamir A. Optimasi air perasan buah merah (Pandanus sp.) pada pemeriksaan telur cacing. J Teknol Lab. 2017;6(1):8-17.

8. Adekunle AA. Studies of age-related changes in the metabolism of eosin in the rat. Mech Ageing Dev. 1978;8(3):219-25. http:/l doi.org/10.1016/0047-6374(78)90020-9

PMid:211356

9. Oveisi M, Sadeghi N, Jannat B, Nilfroush E. Simultaneous determination of carmoisine and ponceau 4R. Food Anal Methods. 2008;1(3):214-9. http://doi.org/10.1007/ s12161-008-9022-7

10. Mason PL, Gaunt IF, Butterworth KR, Hardy J, Kiss IS Grasso P. Long-term toxicity studies of carmoisine in mice. Food Cosmet Toxicol. 1974;12(5-6):601-7. http://doi. org/10.1016/0015-6264(74)90232-6 PMid:4452535

11. Jusuf AA. Histoteknik Dasar. Indonesia: Universitas Indonesia; 2009.

12. WC Analisis dan Aspek Kesehatan Bahan Tambahan Pangan. Bumi Aksara; 2006.

13. Sumarlin LO. Identifikasi Pewarna Sintetik Pada Produk Pangan Yang Beredar di Jakarta dan Ciputat; 2010.

14. Martin A, Swarbick J, Cammarata A. Farmasi Fisik 2. UI Press; 1993.

15. Poedjiadi A. Dasar-Dasar Biokimia. UI Press; 1994.

16. Winarno. Kimia Pangan dan Gizi. Gramedia; 2008.

17. Yusuf Y. Modul Sederhana dan IImiah Untuk BELAJAR KIMIA Pangan dan Gizi. Indonesia: EduCenter Indonesia; 2018.

18. Yazid EN, Lisda. Penuntun Praktikum Biokimia Untuk Mahasiswa Analis. Andi Offset; 2006. 